\title{
Changes in intracellular ion activities induced by adrenaline in human and rat skeletal muscle*
}

\author{
Klaus Ballanyi ${ }^{1}$ and Peter Grafe ${ }^{2}$ \\ 1 Institut für Zoologie I, Universität Düsseldorf, Universitätsstrasse 1, Geb. 26.02, D-4000 Düsseldorf 1, Federal Republic of Germany \\ 2 Physiologisches Institut der Universität München, Pettenkoferstrasse 12, D-8000 München 2, Federal Republic of Germany
}

\begin{abstract}
To study the stimulating effect of adrenaline (ADR) on active $\mathrm{Na}^{+} / \mathrm{K}^{+}$transport we used double-barrelled ion-sensitive micro-electrodes to measure the activities of extracellular $\mathrm{K}^{+}\left(a \mathrm{~K}_{\mathrm{e}}\right)$ and intracellular $\mathrm{Na}^{+}\left(a \mathrm{Na}_{\mathrm{i}}\right)$ in isolated preparations of rat soleus muscle, normal human intercostal muscle and one case of hyperkalemic periodic paralysis (h.p.p.). In these preparations, bath-application of ADR $\left(10^{-6} \mathrm{M}\right)$ resulted in a membrane hyperpolarization and transient decreases $a \mathrm{~K}_{\mathrm{e}}$ and $a \mathrm{Na}_{\mathrm{i}}$ which could be blocked by ouabain $\left(3 \times 10^{-4} \mathrm{M}\right)$. In the h.p.p. muslce a continuous rise of $a \mathrm{Na}_{\mathrm{i}}$ induced by elevation of $a \mathrm{~K}_{\mathrm{e}}$ to $5.2 \mathrm{mM}$ could be stopped by ADR. In addition, the intracellular $\mathrm{K}^{+}$activity $\left(a \mathrm{~K}_{\mathrm{i}}\right)$, the free intracellular $\mathrm{Ca}^{2+}$ concentration $\left(p \mathrm{Ca}_{\mathrm{i}}\right)$ and intracellular $\mathrm{pH}\left(\mathrm{pH}_{\mathrm{i}}\right)$ were monitored in rat soleus muscle. During ADR $a \mathrm{~K}_{\mathrm{i}}$ increased, $\mathrm{pH}_{\mathrm{i}}$ remained constant and intracellular $\mathrm{Ca}^{2+}$ apparently decreased. In conclusion, our data show that ADR primarily stimulates the $\mathrm{Na}^{+} / \mathrm{K}^{+}$pump in mammalian skeletal muscle. This stimulating action is not impaired in the h.p.p. muscle.
\end{abstract}

Key words: Ion activities $-\mathrm{Na}^{+} / \mathrm{K}^{+}$pump - Adrenaline Skeletal muscle - Hyperkalemic periodic paralysis

\section{Introduction}

Catecholamines have a facilitating action on the active $\mathrm{Na}^{+}$/ $\mathrm{K}^{+}$transport in striated muscle (Clausen 1986). This stimulating effect is relevant for the $\mathrm{K}^{+}$homeostasis in skeletal muscle. In humans, hyperkalemia induced by either work or $\mathrm{KCl}$ infusion is accentuated by propanolol and reduced by phentolamine (Williams et al. 1985) or by epinephrine (Rosa et al. 1980). In patients suffering from hyperkalemic periodic paralysis (h.p.p.) hyperkalemia can be suppressed by inhalation of salbutamol (Wang and Clausen 1976; Clausen et al. 1980).

Most of the data concerning catecholamine-induced modulation of muscular $\mathrm{K}^{+}$homeostasis was obtained by flame photometry or radioactive tracer studies. At present, no information is available about the behaviour of the ion activities in mammalian and, especially, in human skeletal muscle in the presence of catecholamines. Therefore, we have measured the activities of extracellular $\mathrm{K}^{+}\left(a \mathrm{~K}_{\mathrm{e}}\right)$ as

Offprint requests to: $\mathrm{K}$. Ballanyi

* Parts of the results have been presented to the German Physiological Society (Ballanyi and Grafe 1987) well as intracellular $\mathrm{Na}^{+}\left(a \mathrm{Na}_{\mathrm{i}}\right)$ with double-barrelled ionsensitive micro-electrodes in rat soleus muscle, in normal human intercostal muscle, and in one case of h.p.p. In addition, the intracellular $\mathrm{K}^{+}$activity $\left(a \mathrm{~K}_{\mathrm{i}}\right)$, the free intracellular $\mathrm{Ca}^{2+}$ concentration $\left(p \mathrm{Ca}_{\mathrm{i}}\right)$ and intracellular $\mathrm{pH}\left(\mathrm{pH}_{\mathrm{i}}\right)$ were measured in the rat muscle during adrenaline (ADR), in order to see possible effects of catecholamines on ion transport mechanisms other than the $\mathrm{Na}^{+} / \mathrm{K}^{+}$pump.

The data show that im mammalian skeletal muscle ADR mainly affects the $\mathrm{Na}^{+}$and $\mathrm{K}^{+}$activities as a result of $\mathrm{Na}^{+}$/ $\mathrm{K}^{+}$pump stimulation. This facilitating action of ADR is not impaired in muscle fibers of one patient suffering from h.p.p.

\section{Materials and methods}

The experiments were performed on isolated preparations of rat soleus muscle, of normal external intercostal muscle from patients without muscle diseases who had to undergo thoracic surgery and of external intercostal muscle from one patient who had suffered from attacks of hyperkalemic periodic paralysis (h.p.p.). The clinical and laboratory findings of this patient and his relatives have been described previously (Camacho 1984). The patient gave informed consent for an external intercostal muscle biopsy to be taken. The specimen was obtained under general anaesthesia without the use of muscle relaxants. The study was approved by the Ethics Commission of the Technical University of Munich and carried out in abidance with the Helsinki-convention.

The preparations were placed into a perspex chamber (volume $2 \mathrm{ml}$ ) and superfused at $37^{\circ} \mathrm{C}$ with a solution of the following composition (concentrations in $\mathrm{mM}$ ): $\mathrm{NaCl} 118$, $\mathrm{KCl} 3, \mathrm{NaHCO}_{3} 25, \mathrm{NaH}_{2} \mathrm{PO}_{4} 1.2, \mathrm{MgCl}_{2} 1.0, \mathrm{CaCl}_{2} 1.5$ and glucose 10 (gassed with $95 \% \mathrm{O}_{2}, 5 \% \mathrm{CO}_{2} ; \mathrm{pH}$ 7.4). A high $\mathrm{K}^{+}$solution was obtained by addition of $4 \mathrm{mM} \mathrm{KCl}$ to the standard solution. In the $\mathrm{NH}_{4} \mathrm{Cl}$ solution $15 \mathrm{mM}$ $\mathrm{NaCl}$ was substituted by $\mathrm{NH}_{4} \mathrm{Cl}$. ADR, tetrodotoxin (TTX) and ouabain were added to the superfusion fluid (all chemicals in this study were purchased from Sigma, Munich, FRG).

The methods for the construction and calibration of the double-barrelled ion-sensitive micro-electrodes are described in detail elsewhere (Ballanyi et al. 1984; Grafe et al. 1985). In brief, theta-capillaries were pulled with a BrownFlaming type micro-electrode puller (Sutter Instrument Co., San Francisco, CA, USA). Silanization of one barrel with hexamethyldisilazane (Sigma) was performed at $400^{\circ} \mathrm{C}$ for 

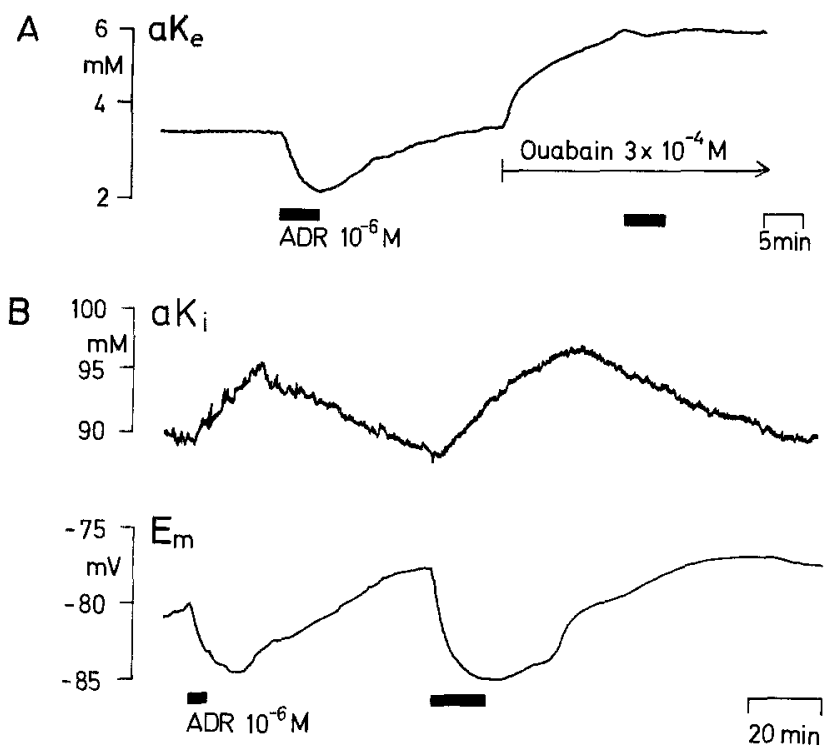

Fig. 1. A Effects of adrenaline $(A D R)$ on extracellular $\mathrm{K}^{+}$activity $\left(a \mathrm{~K}_{\mathrm{e}}\right)$ in rat soleus muscle. Bath-application of ADR $\left(10^{-6} \mathrm{M}\right)$ resulted in a transient decrease of $a \mathrm{~K}_{\mathrm{e}}$. In the presence of ouabain $\left(3 \times 10^{-4} \mathrm{M}\right)$ the $a \mathrm{~K}_{\mathrm{e}}$ decrease was blocked. B Effects of ADR on intracellular $\mathrm{K}^{+}$activity $\left(a \mathrm{~K}_{\mathrm{i}}\right)$ and membrane potential $\left(E_{\mathrm{m}}\right)$ in rat soleus muscle. Two applications of ADR via the bathing solution showed the same effect: transient $a \mathrm{~K}_{\mathrm{i}}$ increases were accompanied by a membrane hyperpolarization

$20 \mathrm{~min}$. During this period nitrogen was applied under pressure to the other barrel in order to prevent the silane from entering. Later on, a drop of liquid ion exchanger was injected into the silanized barrel, which was then backfilled with an internal reference solution. The reference barrel was filled with electrolyte solution (1 M Mg-acetate). The following combinations of ion-exchanger and backfilling solution were used: $\mathrm{K}^{+}$-sensitive micro-electrodes (Corning $477317,200 \mathrm{mM} \mathrm{KCl}$ ); $\mathrm{Na}^{+}$-sensitive micro-electrodes (Fluka $71176,200 \mathrm{mM} \mathrm{NaCl}$ ); $\mathrm{Ca}^{2+}$-sensitive micro-electrodes (Fluka 21048, $200 \mathrm{mM} \mathrm{CaCl}$ ); $\mathrm{pH}$-sensitive microelectrodes (Fluka 82500, $\mathrm{KH}_{2} \mathrm{PO}_{4} 40 \mathrm{mM}+\mathrm{NaOH} 23 \mathrm{mM}$ $+\mathrm{NaCl} 15 \mathrm{mM}$ ).

$\mathrm{K}^{+}$-sensitive electrodes were calibrated in solutions containing 3,12 and $60 \mathrm{mM} \mathrm{KCl}$ with a constant background of $150 \mathrm{mM} \mathrm{NaCl}$. The mean values for the slope and the selectivity coefficient versus $\mathrm{Na}^{+}$were $53.3 \pm 4.6 \mathrm{mV}$ and $0.019 \pm 0.007$ (mean \pm standard deviation, $n=21$ ). $\mathrm{Na}^{+}$sensitive electrodes were calibrated by comparison of the $\mathrm{Na}^{+}$signal in the physiological solution with solutions containing different $\mathrm{Na}^{+}$concentrations $(1,3,12,30$ and $60 \mathrm{mM}$ ) with a variable background of $\mathrm{K}^{+}$to keep the sum of $\mathrm{Na}^{+}$and $\mathrm{K}^{+}$at $150 \mathrm{mM}$. The $\mathrm{Ca}^{2+}$ concentration in these calibration solutions was buffered to $10^{-7} \mathrm{M}$ to imitate the $\mathrm{Ca}^{2+}$ contribution to the $\mathrm{Na}^{+}$signal during impalement. Interference of the $\mathrm{Na}^{+}$measurements with $\mathrm{Ca}^{2+}$ is negligible as intracellular $\mathrm{Ca}^{2+}$ concentration is about $10^{-7} \mathrm{M}$ in skeletal muscle (Weingart and Hess 1984; this study). All values of intracellular $\mathrm{Na}^{+}$and $\mathrm{K}^{+}$and of extracellular $\mathrm{K}^{+}$ $\left(a \mathrm{Na}_{\mathrm{i}}, a \mathrm{~K}_{\mathrm{i}}, a \mathrm{~K}_{\mathrm{e}}\right)$ are given in activities assuming an activity coefficient of 0.74 for these ions. The $\mathrm{Ca}^{2+}$-sensitive electrodes were calibrated in terms of free ion concentrations according to calibration solutions given by Tsien and Rink (1981). The $\mathrm{Ca}^{2+}$-electrodes had slopes between 27 and
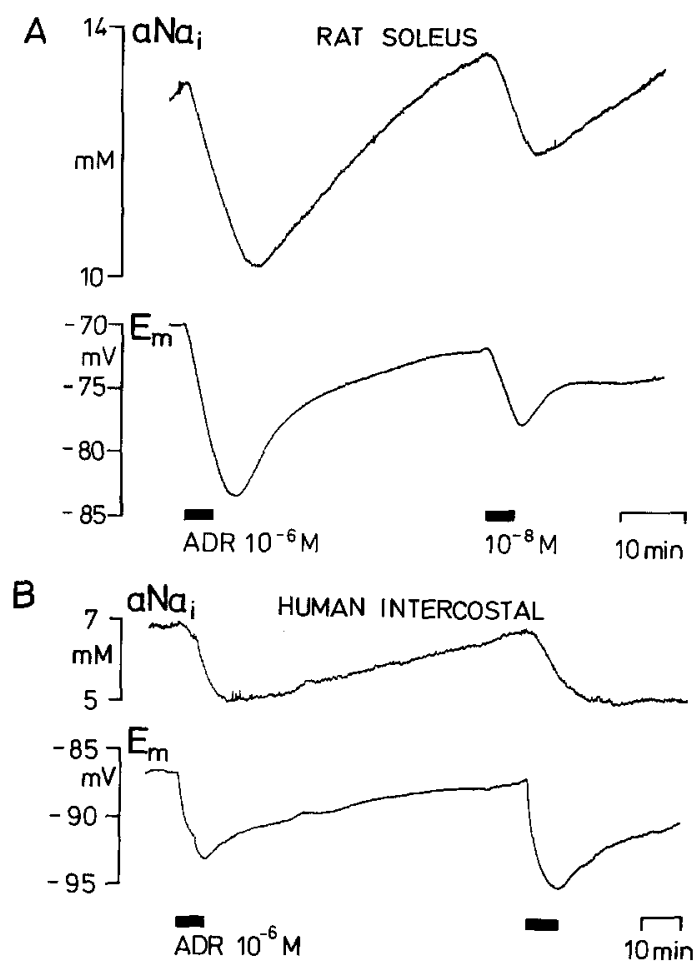

Fig. 2A, B. Effects of adrenaline $(A D R)$ on intracellular $\mathrm{Na}^{+}$activity $\left(a \mathrm{Na}_{\mathrm{i}}\right)$ and membrane potential $\left(E_{\mathrm{m}}\right)$ in rat soleus $(\mathrm{A})$ and human intercostal muscle (B). In both, rat and human muscles ADR $\left(10^{-6} \mathrm{M}, 5 \mathrm{~min}\right)$ produced very similar hyperpolarizations and transient decreases of $a \mathrm{Na}_{\mathrm{i}}$. Note, that in the rat muscle $10^{-8} \mathrm{MADR}$ also had a clearly detectable effect on $E_{\mathrm{m}}$ and $a \mathrm{Na}_{\mathrm{i}}$. The kinetics of the $a \mathrm{Na}_{\mathrm{i}}$ decreases with respect to the ADR induced membrane hyperpolarizations was considerably variable for each muscle fiber (compare Figs. 2, 3 and 4). Such differences are probably due to the intracellular position of the electrodes or to the volume of individual muscle fibers

$30 \mathrm{mV}$ at $p \mathrm{Ca} 3-6$, between 15 and $24 \mathrm{mV}$ at $p \mathrm{Ca} 6-7$, and between 5 and $11 \mathrm{mV}$ at $p \mathrm{Ca} 7-8$. Individual calibration curves were plotted for each electrode. The electrodes were also tested for their sensitivity to $\mathrm{Na}^{+}$. Changing $\mathrm{Na}^{+}$from 5 to $10 \mathrm{mM}$ at $p \mathrm{Ca} 7$ resulted in a voltage change of the $\mathrm{Ca}^{2+}$-electrodes by about $1 \mathrm{mV}$ indicating an apparent increase of $\mathrm{Ca}^{2+}$ (see Fig. 5B). pH-sensitive electrodes were calibrated in different buffer-solutions (HEPES-buffer: $\mathrm{pH}$ 7.7; PIPES-buffer: $\mathrm{pH} 6.7$ and TAPS-buffer: $\mathrm{pH}$ 8.4). The $\mathrm{pH}$-electrodes had slopes between 56 and $60 \mathrm{mV}$. Intracellular impalements were achieved by means of a piezo driven micro-manipulator (built by M. Frankenberger, Munich, FRG).

\section{Results}

Effects of adrenaline on extra- and intracellular $\mathrm{K}^{+}$activities

Rat soleus muscle. The extracellular $\mathrm{K}^{+}$activity $\left(a \mathrm{~K}_{\mathrm{e}}\right)$ was measured with double-barrelled ion-sensitive micro-electrodes in 14 fiber bundles of rat soleus muscle. In some fiber bundles resting $a \mathrm{~K}_{\mathrm{e}}$ was slightly higher than in the bulk solution probably due to $\mathrm{K}^{+}$leakage from injured muscle fibers. In all bundles bath-application of $10^{-6} \mathrm{M}$ adrenaline (ADR, $5 \mathrm{~min}$ ) revealed a transient decrease in $a \mathrm{~K}_{\mathrm{e}}$ of $0.9 \pm 0.3 \mathrm{mM}$ (mean \pm standard deviation). An example for 


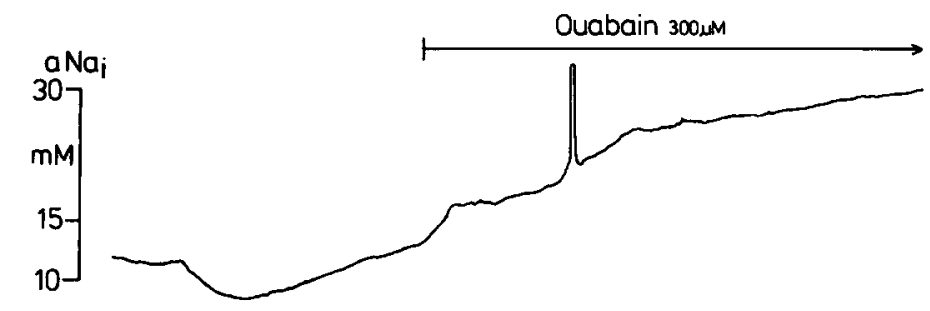

Fig. 3

Effects of ouabain on adrenaline $(A D R)$ induced changes of membrane potential $\left(E_{\mathrm{m}}\right)$ and intracellular $\mathrm{Na}^{+}$activity $\left(a \mathrm{Na}_{\mathrm{i}}\right)$ in rat soleus muscle. ADR $\left(10^{-6} \mathrm{M}, 5 \mathrm{~min}\right)$ resulted in a hyperpolarization of about $12 \mathrm{mV}$ and an $a \mathrm{Na}_{\mathrm{i}}$ decrease of $3 \mathrm{mM}$. After recovery from ADR, ouabain $\left(3 \times 10^{-4} \mathrm{M}\right)$ was added. $E_{\mathrm{m}}$ depolarized by $15 \mathrm{mV}$ and reached a stable value at $-55 \mathrm{mV}$ after about $25 \mathrm{~min}$. In contrast, a continuous rise of $a \mathrm{Na}_{\mathrm{i}}$ could be observed in the presence of ouabain. An interpretation of the effects of the first ADR application during ouabain is not possible because of an unstable recording situation. The following application revealed an almost complete blockage of the ADR induced hyperpolarization and $a \mathrm{Na}_{\mathrm{i}}$ decrease. The blockage of the hyperpolarization was not due to the ouabain dependent depolarization as the ADR hyperpolarization was not impaired in muscle fibers with low resting potentials or in fibers that were depolarized by elevation of extracellular $\mathrm{K}^{+}$

such a measurement is given in Fig. $1 \mathrm{~A}$. In the beginning of the recording $a \mathrm{~K}_{\mathrm{e}}$ decreased from about 3 to $2 \mathrm{mM}$ during ADR. After the recovery of $a \mathrm{~K}_{\mathrm{e}}$ ouabain $\left(3 \times 10^{-4} \mathrm{M}\right)$ was added. $a \mathrm{~K}_{\mathrm{e}}$ baseline increased to $6 \mathrm{mM}$ as a result of $\mathrm{Na}^{+} /$ $\mathrm{K}^{+}$pump inhibition. In the presence of ouabain the ADRinduced $a \mathrm{~K}_{\mathrm{e}}$ decrease was blocked. The mean intracellular $\mathrm{K}^{+}$activity $\left(a \mathrm{~K}_{\mathrm{i}}\right)$ as measured in 10 muscle fibers with an average membrane resting potential $\left(E_{\mathrm{m}}\right)$ of $-78 \pm 2.8 \mathrm{mV}$ was $96.9 \pm 9.5 \mathrm{mM}$. ADR $\left(10^{-6} \mathrm{M}, 5 \mathrm{~min}\right)$ resulted in an $a \mathrm{~K}_{\mathrm{i}}$ increase of $4.03 \pm 1.8 \mathrm{mM}$ in these fibers accompanied by a membrane hyperpolarization of $8.5 \pm 3.1 \mathrm{mV}$. Figure $1 \mathrm{~B}$ illustrates two subsequent applications of ADR. The 16 min superfusion with ADR led to a prolongation of the hyperpolarization as well as of the $a \mathrm{~K}_{\mathrm{i}}$ increase with respect to the $5 \mathrm{~min}$ ADR-application in the beginning of the recording.

Human intercostal muscle. $a \mathrm{~K}_{\mathrm{e}}$ during $\mathrm{ADR}$ was also measured in 5 fiber bundles of normal human intercostal muscle ( 5 different preparations) and in one case of hyperkalemic periodic paralysis (h.p.p.). ADR $\left(10^{-6} \mathrm{M}, 5 \mathrm{~min}\right)$ produced a mean $a \mathrm{~K}_{\mathrm{e}}$ decrease of $0.27 \pm 0.12 \mathrm{mM}$ in normal human muscle. In the h.p.p. muscle very similar $a \mathrm{~K}_{\mathrm{e}}$ decreases during ADR could be observed (see upper trace in Fig. 4).

\section{Effects of adrenaline on intracellular $\mathrm{Na}^{+}$activity}

Rat soleus muscle. The mean intracellular $\mathrm{Na}^{+}$activity $\left(a \mathrm{Na}_{\mathrm{i}}\right)$ as measured in 11 fibers of rat soleus muscle with a mean $E_{\mathrm{m}}$ of $-79.2 \pm 5.4 \mathrm{mV}$ was $11.5 \pm 2.4 \mathrm{mM}$. During ADR $\left(10^{-6} \mathrm{M}, 5 \mathrm{~min}\right) a \mathrm{Na}_{\mathrm{i}}$ in these fibers transiently decreased by $1.73 \pm 0.9 \mathrm{mM}$ accompanied by a membrane hyperpolarization of $11 \pm 2.9 \mathrm{mV}$. Figure $2 \mathrm{~A}$ shows that $10^{-8} \mathrm{M}$ ADR produced a smaller hyperpolarization and $a \mathrm{Na}_{\mathrm{i}}$ decrease with respect to $10^{-6} \mathrm{M}$ ADR applied in the beginning of the recording. In 4 cells tested ouabain $\left(3 \times 10^{-4} \mathrm{M}\right)$ blocked both the ADR-induced hyperpolarization and the $a \mathrm{Na}_{\mathrm{i}}$ decrease as illustrated in Fig. 3 .

Human intercostal muscle. $a \mathrm{Na}_{\mathrm{i}}$ in 6 fibers of normal human intercostal muscle (3 different preparations) with a mean $E_{\mathrm{m}}$ of $-81.8 \pm 3.8 \mathrm{mV}$ was $9.6 \pm 1.2 \mathrm{mM}$. ADR $\left(10^{-6} \mathrm{M}\right.$, $5 \mathrm{~min}$ ) hyperpolarized these fibers by $9.8 \pm 2.2 \mathrm{mV}$ and de-
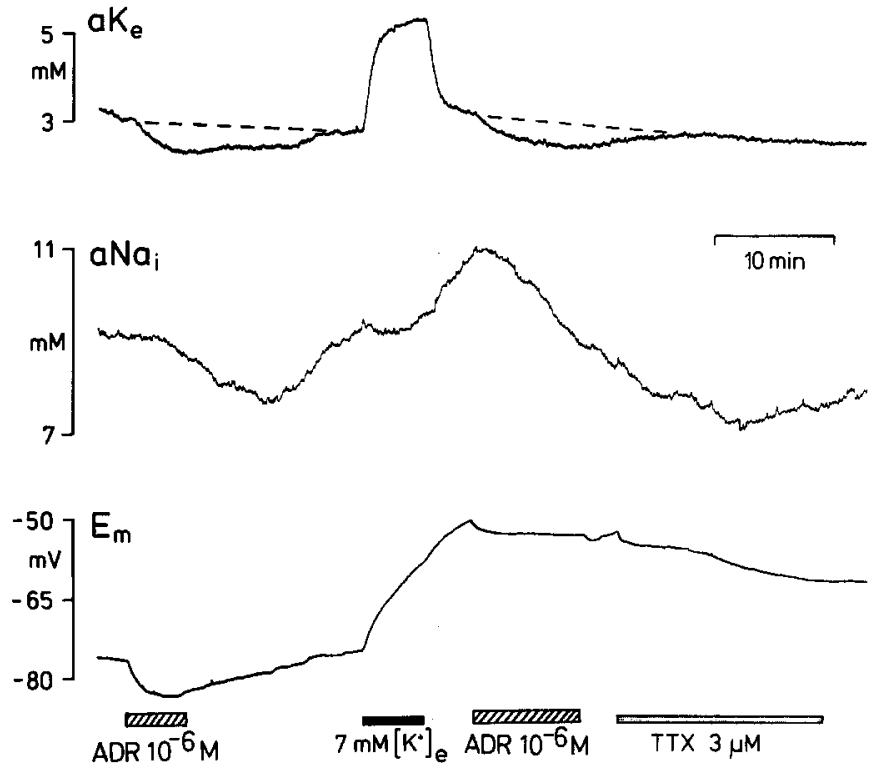

Fig. 4. Effects of adrenaline $(A D R)$ on membrane potential $\left(E_{\mathrm{m}}\right)$ and the activitites of extracellular $\mathrm{K}^{+}\left(a \mathrm{~K}_{\mathrm{e}}\right)$ and intracellular $\mathrm{Na}^{+}$ $\left(a \mathrm{Na}_{\mathrm{i}}\right)$ in an intercostal muscle fiber of a patient with hyperkalemic periodic paralysis (h.p.p.). ADR $\left(10^{-6} \mathrm{M}, 5 \mathrm{~min}\right)$ decreased $a \mathrm{~K}_{\mathrm{e}}$ and $a \mathrm{Na}_{\mathrm{i}}$ and hyperpolarized $E_{\mathrm{m}}$. A short-time increase of the $\mathrm{K}^{+}$ concentration of the superfusion-fluid to $7 \mathrm{mM}$ elicited an excessive depolarization and $a \mathrm{Na}_{\mathbf{i}}$ increase. In this situation, ADR could stop the depolarization and decreased $a \mathrm{Na}_{\mathbf{i}}$ below its resting level. Subsequently, tetrodotoxin (TTX) was applied to restore resting potential (see Lehmann-Horn et al. 1987)

creased $a \mathrm{Na}_{\mathrm{i}}$ by $2.3 \pm 1.1 \mathrm{mM}$. Figure $2 \mathrm{~B}$ illustrates the effects of two subsequent applications of ADR on $E_{\mathrm{m}}$ and $a \mathrm{Na}_{\mathrm{i}}$.

\section{Effects of adrenaline on $\mathrm{a} K_{\mathrm{e}}$ and $\mathrm{a} N a_{\mathrm{i}}$ in human h.p.p. muscle}

$a \mathrm{~K}_{\mathrm{e}}, a \mathrm{Na}_{\mathrm{i}}$ and $E_{\mathrm{m}}$ were measured simultaneously in fiber bundles of human intercostal muscle from a patient with hyperkalemic periodic paralysis (h.p.p.). In the beginning of Fig. 4 it is shown that ADR $\left(10^{-6} \mathrm{M}, 5 \mathrm{~min}\right)$ produced the typical effects on $a \mathrm{~K}_{\mathrm{e}}, a \mathrm{Na}_{\mathrm{i}}$ and $E_{\mathrm{m}}$. A subsequent increase of the $\mathrm{K}^{+}$concentration of the superfusion fluid to $7 \mathrm{mM}$ 


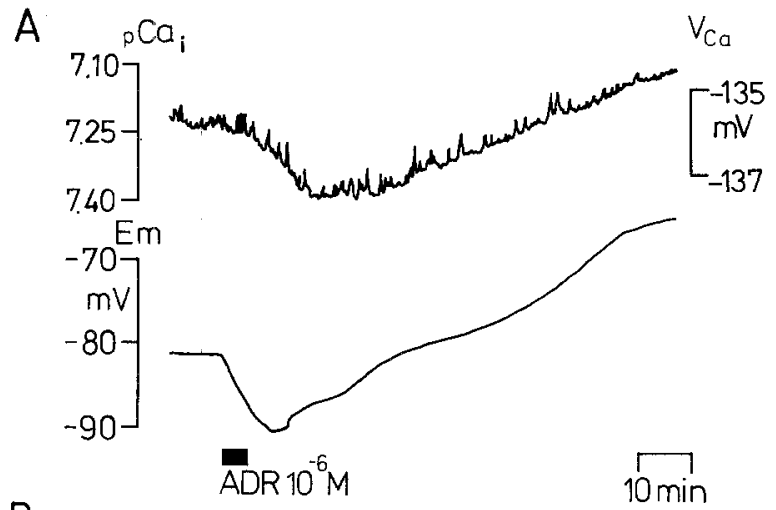

B
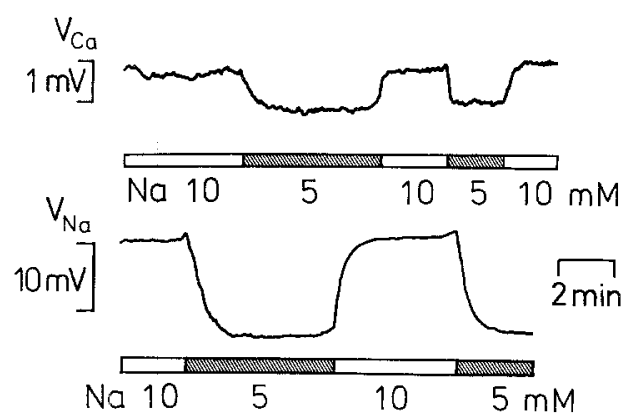

Fig. 5 A, B. Effects of adrenaline $(A D R)$ on intracellular free $\mathrm{Ca}^{2+}$ concentration $\left(p \mathrm{Ca}_{\mathrm{i}}\right)$ and membrane potential $\left(E_{\mathrm{m}}\right)$ in rat soleus muscle. A A.DR $\left(10^{-6} \mathrm{M}, 5 \mathrm{~min}\right)$ resulted in a hyperpolarization of about $10 \mathrm{mV}$ accompanied by a change of the difference signal of the $\mathrm{Ca}^{2+}$-sensitive micro-electrode from about -136 to $-138 \mathrm{mV}$ indicating a decrease of intracellular $\mathrm{Ca}^{2+}$. B Testing of the $\mathrm{Na}^{+}$ sensitivity of a typical $\mathrm{Ca}^{2+}$-sensitive (upper trace) and $\mathrm{Na}^{+}$-sensitive micro-electrode (lower trace) in solutions with $p \mathrm{Ca} 7$ and 5 or $10 \mathrm{mM} \mathrm{Na}^{+}$concentration. The $\mathrm{Ca}^{2+}$-electrode responded with $1 \mathrm{mV}$ to the change between 5 and $10 \mathrm{mM} \mathrm{Na}^{+}$whereas the $\mathrm{Na}^{+}$. electrode responded with the typical voltage jump of about $15 \mathrm{mV}$

elicited an excessive depolarization and an $a \mathrm{Na}_{\mathrm{i}}$ increase, which is typical for h.p.p. muscle (Lehmann-Horn et al. 1987). ADR, applied in this situation, reversed the $a \mathrm{Na}_{\mathrm{i}}$ increase into the typical $a \mathrm{Na}_{\mathrm{i}}$ decrease. Due to the long depolarization tetrodotoxin only slowly restored $E_{\mathrm{m}}$ in this h.p.p. muscle fiber.

\section{Effects of adrenaline on intracellular $\mathrm{Ca}^{2+}$ and $\mathrm{pH}$ in rat soleus muscle}

The free intracellular $\mathrm{Ca}^{2+}$ concentration $\left(p \mathrm{Ca}_{\mathrm{i}}\right)$ as measured in 6 rat soleus muscle fibers with an average $E_{\mathrm{m}}$ of $-82.7 \pm 2.5 \mathrm{mV}$ was $6.84 \pm 0.33$ as derived from a mean intracellular difference signal of the $\mathrm{Ca}^{2+}$-sensitive microelectrodes $\left(V_{\mathrm{Ca}_{\mathrm{a}}}\right)$ of $-129.7 \pm 6.1 \mathrm{mV}$. This $p \mathrm{Ca}_{\mathrm{i}}$ value corresponds to a free intracellular $\mathrm{Ca}^{2+}$ concentration of $145 \mathrm{nM}$. In the presence of ADR $\left(10^{-6} \mathrm{M}, 5 \mathrm{~min}\right) V_{\mathrm{Ca}}$ decreased by $1.8 \pm 0.09 \mathrm{mV}$ indicating an apparent decrease of intracellular $\mathrm{Ca}^{2+}$. An example of such measurements is given in Fig. 5A. Due to interference of the $\mathrm{Ca}^{2+}$-sensitive resin with $\mathrm{Na}^{+}$some portion of the $\mathrm{Ca}^{2+}$ signal during ADR might result from the transient decrease of $a \mathrm{Na}_{\mathrm{i}}$ (compare Fig. $2 \mathrm{~A}$ ). $V_{\mathrm{Ca}}$ is changing by about $1 \mathrm{mV}$ in test solutions with 5 and $10 \mathrm{mM} \mathrm{Na}^{+}(p \mathrm{Ca} 7)$ as illustrated in Fig. 5B. However, one observation argues for a real decrease of intracellular $\mathrm{Ca}^{2+}$ during ADR. In most cases the observed fall
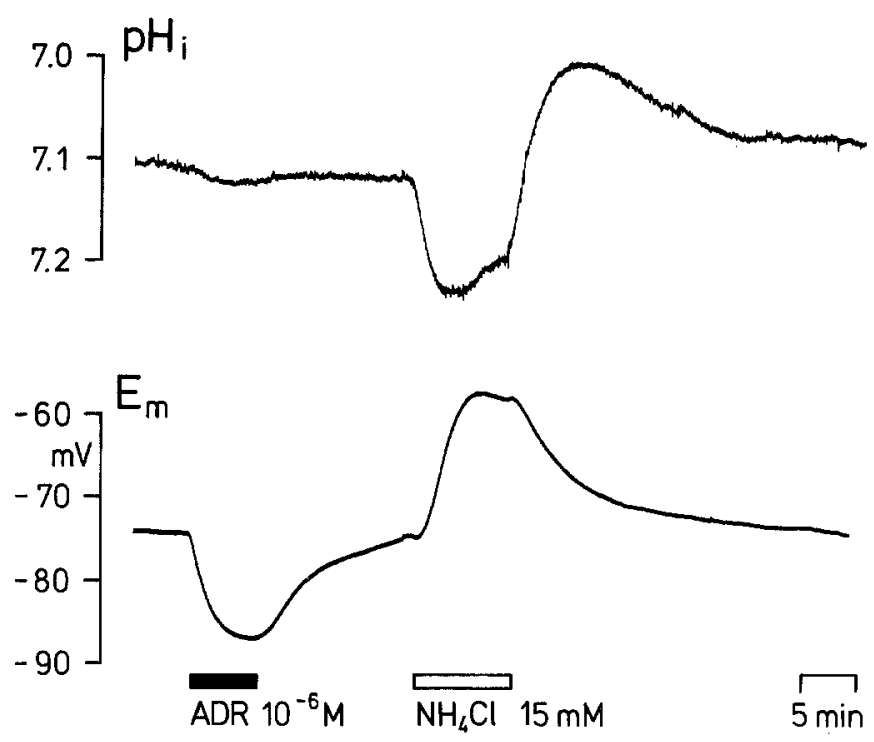

Fig. 6. Effects of adrenaline $(A D R)$ on intracellular $\mathrm{pH}\left(\mathrm{pH}_{\mathrm{i}}\right)$ and membrane potential $\left(E_{\mathrm{m}}\right)$ in rat soleus muscle. In spite of a prominent hyperpolarization, $\mathrm{pH}_{\mathrm{i}}$ remained constant during ADR $\left(10^{-6} \mathrm{M}, 5 \mathrm{~min}\right)$. The sensitivity of the $\mathrm{pH}$-sensitive micro-electrode was tested by superfusing the muscle with a solution containing $15 \mathrm{mM} \mathrm{NH} \mathrm{NH}_{4} \mathrm{Cl}$ which is known to cause a biphasic alkaline-acid going shift of $\mathrm{pH}_{\mathrm{i}}$

in $a \mathrm{Na}_{\mathbf{i}}$ in the presence of ADR was considerably smaller than $5 \mathrm{mM}$. Nevertheless, $V_{\mathrm{Ca}}$ changes were almost twice as large compared to the voltage reading of a $\mathrm{Ca}^{2+}$-sensitive micro-electrode when the $\mathrm{Na}^{+}$concentration decreased from 10 to $5 \mathrm{mM}$ (see Discussion).

Intracellular $\mathrm{pH}\left(\mathrm{pH}_{\mathrm{i}}\right)$ as measured in 7 rat soleus muscle fibers with a mean $E_{\mathrm{m}}$ of $-76 \pm 2.9 \mathrm{mV}$ was $7.04 \pm 0.37$. During $\mathrm{ADR}\left(10^{-6} \mathrm{M}, 5 \mathrm{~min}\right) \mathrm{pH}_{\mathrm{i}}$ in these fibers remained constant despite of the typical ADR-induced hyperpolarization of $8.8 \pm 1.4 \mathrm{mV}$. Figure 6 illustrates that application of $10^{-6} \mathrm{M}$ ADR had almost no effect on intracellular $\mathrm{pH}$ although this muscle fiber hyperpolarized by more than $10 \mathrm{mV}$. In contrast, superfusion with a solution containing $15 \mathrm{mM} \mathrm{NH}_{4} \mathrm{Cl}$ had the typical effects on $\mathrm{pH}_{\mathrm{i}}$ (Thomas 1984). An initial alkalinization was followed by an acidification after the washout of $\mathrm{NH}_{4} \mathrm{Cl}$.

\section{Discussion}

In the present study measurements of extra- and intracellular ion activities were used to investigate the catecholamineinduced stimulation of the $\mathrm{Na}^{+} / \mathrm{K}^{+}$pump in rat soleus muscle, in normal human intercostal muscle and in one case of hyperkalemic periodic paralysis (h.p.p.). The ion activities that were primarily affected by the action of adrenaline (ADR) were $a \mathrm{Na}_{\mathrm{i}}, a \mathrm{~K}_{\mathrm{i}}$ and $a \mathrm{~K}_{\mathrm{e}}$. The observed decreases of $a \mathrm{~K}_{\mathrm{e}}$ and $a \mathrm{Na}_{\mathrm{i}}$ as well as the membrane hyperpolarization during ADR were very similar in these preparations. In addition, ADR resulted in an increase of the intracellular $\mathrm{K}^{+}$activity $\left(a \mathrm{~K}_{\mathrm{i}}\right)$ as measured in rat soleus muscle. These results confirm earlier measurements of cellular $\mathrm{Na}^{+}$content, serum $\mathrm{K}^{+}$concentrations, and of $\mathrm{Na}^{+}$and $\mathrm{K}^{+}$fluxes in rat soleus muscle (Dockry et al. 1966; Clausen and Flatman 1977, 1980; Pfliegler et al. 1983). Furthermore, the magnitude of the average decreases of $a \mathrm{Na}_{\mathrm{i}}(1.73 \mathrm{mM}$ in rat soleus 
and $2.3 \mathrm{mM}$ in human intercostal muscle) very closely resembled catecholamine-induced decreases of $a \mathrm{Na}_{\mathbf{i}}$ as measured with $\mathrm{Na}^{+}$-sensitive micro-electrodes in different heart tissues as dog heart Purkinje and ventricular trabecular muscle fibers (Wasserstrom et al. 1982), canine Purkinje fibers (Lee and Vasalle 1983) and isolated myocytes of the rabbit (Désilets and Baumgarten 1986). In contrast, in sheep heart Purkinje fibers noradrenaline leads to a small $a \mathrm{Na}_{\mathrm{i}}$ increase (Glitsch and Rasch 1986). A quantitative comparison of the $a \mathrm{Na}_{\mathrm{i}}$ and $a \mathrm{~K}_{\mathrm{i}}$ changes in this study with intracellular concentration changes of $\mathrm{Na}^{+}$and $\mathrm{K}^{+}$as calculated from flux measurements is difficult because of controversies concerning the intracellular activity coefficients, especially for $\mathrm{Na}^{+}$, in muscle tissue (MacDermott 1984).

The close relationship between the time courses of the observed $\mathrm{Na}^{+}$and $\mathrm{K}^{+}$activity and membrane potential changes favours a stimulation of the electrogenic $\mathrm{Na}^{+} / \mathrm{K}^{+}$ pump as the ionic mechanism for the effects of ADR as proposed for the majority of previous investigations (Clausen 1986). A shift of the $\mathrm{K}^{+}$equilibrium potential towards a more negative value also contributes to the membrane hyperpolarization during ADR (Clausen and Flatman 1977). An increase of the $\mathrm{K}^{+}$permeability by catecholamines (Zemkova et al. 1985) is not likely as such an effect should result in an, at least initial, decrease of $a \mathrm{~K}_{\mathrm{i}}$ and an increase of $a \mathrm{~K}_{\mathrm{e}} \cdot a \mathrm{Na}_{\mathrm{i}}$ according to this assumption, should not decrease but increase during ADR due to an increased driving force for $\mathrm{Na}^{+}$facilitating $\mathrm{Na}^{+}$entry into the muscle fibers. Furthermore, the decreases of $a \mathrm{~K}_{\mathrm{e}}$ and $a \mathrm{Na}_{\mathrm{i}}$ as well as the hyperpolarization could be blocked by ouabain, a specific inhibitor of the $\mathrm{Na}^{+} / \mathrm{K}^{+}$pump.

In the h.p.p. muscle an elevation of the extracellular $\mathrm{K}^{+}$concentration to $7 \mathrm{mM}$ elicited an excessive membrane depolarization and a continuous $a \mathrm{Na}_{\mathrm{i}}$ increase similar to observations in intercostal muscle fibers of a different h.p.p. patient (Lehmann-Horn et al. 1987). In this situation, ADR could restore $a \mathrm{Na}_{\mathrm{i}}$ resting level. This stimulating effect of ADR is in accordance with other studies on h.p.p. (Wang and Clausen 1976; Clausen et al. 1980; Bendheim et al. 1985) and indicates that the $\mathrm{Na}^{+} / \mathrm{K}^{+}$pump is not impaired in this muscle disease as proposed by Brooks (1969). However, ADR did not completely repolarize the membrane in spite of a return of $a \mathrm{~K}_{e}$ and $a \mathrm{Na}_{\mathrm{i}}$ to normal levels. This supports the idea that an abnormal increase in a TTX-sensitive $\mathrm{Na}^{+}$conductance may be the primary cause for the excessive membrane depolarization seen in h.p.p. muscle fibers (Lehmann-Horn et al. 1987).

Previous reports established an involvement of $\mathrm{Ca}^{2+}$ in catecholamine-elicited hyperpolarization in skeletal muscle (Kozachuk and Phillis 1978). Therefore, intracellular $\mathrm{Ca}^{2+}$ $\left(p \mathrm{Ca}_{\mathrm{i}}\right)$ was measured in rat soleus muscle. The interpretation of the observed apparent decrease of intracellular $\mathrm{Ca}^{2+}$ during ADR is complicated by the sensitivity of the $\mathrm{Ca}^{2+}$ sensor (Fluka 21048) for $\mathrm{Na}^{+}$. The $\mathrm{Ca}^{2+}$-sensitive microelectrodes responded to calibration solutions with 5 and $10 \mathrm{mM} \mathrm{Na}^{+}$concentration ( $p \mathrm{Ca} 7$ ) with a voltage-signal of $1 \mathrm{mV}$. The average change of the intracellular $\mathrm{Ca}^{2+}$ signal during ADR was $1.8 \mathrm{mV}$. As the observed decreases of $a \mathrm{Na}_{\mathbf{i}}$ in soleus muscle were considerably smaller than $5 \mathrm{mM}$ $(1.73 \mathrm{mM})$ the contribution of $\mathrm{Na}^{+}$to the $\mathrm{Ca}^{2+}$ signal should be less than $1 \mathrm{mV}$. Several mechanisms could be responsible for a decrease of muscular $\mathrm{Ca}^{2+}$ during $\mathrm{ADR}$. $\mathrm{A} \mathrm{Na}{ }^{+} / \mathrm{Ca}^{2+}$ exchange normally extruding cellular $\mathrm{Ca}^{2+}$ by use of the energy stored in the transmembraneous $\mathrm{Na}^{+}$ gradient would be stimulated by a decrease of $a \mathrm{Na}_{\mathrm{i}}$. The opposite mechanism i.e. an increase of cytosolic free calcium due to an inhibition of $\mathrm{Na}^{+} / \mathrm{K}^{+}$pump has been reported for rat ventricular myocytes (Sheu et al. 1984). Alternatively, $\mathrm{Ca}^{2+}$ could be taken up into the sarcoplasmic reticulum as it is known for heart tissue. The $\mathrm{Ca}^{2+}$ measurements argue against the hypotheses that catecholamines in mammalian skeletal muscle lead to a release of $\mathrm{Ca}^{2+}$ from intracellular stores like sarcoplasmic reticulum or mitochondria (Rasmussen and Clausen 1982) or significantly increase intracellular $\mathrm{Ca}^{2+}$ concentration as a result of an enhanced probability of single $\mathrm{Ca}^{2+}$ channel activation as suggested by Zemkova et al. (1985).

Using $\mathrm{pH}$-sensitive micro-electrodes no changes of intracellular $\mathrm{pH}\left(\mathrm{pH}_{\mathrm{i}}\right)$ could be detected in rat soleus muscle during ADR. Therefore, stimulation of the $\mathrm{Na}^{+} / \mathrm{K}^{+}$pump by $\mathrm{ADR}$ does not seem to be accompanied by a massive energy consumption and subsequent lactate production as it is the case in working muscle (Steinhagen et al. 1976). This is in accordance with the finding that the total energetic cost of active $\mathrm{Na}^{+} / \mathrm{K}^{+}$transport remains low even during stimulation with ADR (Chinet and Clausen 1984).

Acknowledgements. This study was supported by the Deutsche Forschungsgemeinschaft (SFB 220). The collaboration with Dr. F. Lehmann-Horn (Technical University of Munich) is gratefully acknowledged. We would also like to thank Ms. G. Schneider and Mrs. C. Müller for expert technical assistance, Ms. I. Englmaier for participation in some of the experiments, Dr. J. W. Deitmer for comments on the manuscript, and Mrs. M. Hirsinger for typing of the manuscript.

\section{References}

Ballanyi K, Grafe P (1987) Effects of catecholamines on intracellular ion activities in rat and human skeletal muscle. Pflügers Arch 408:R82

Ballanyi K, Grafe P, Reddy MM, ten Bruggencate G (1984) Different types of potassium transport linked to carbachol and $\gamma$-aminobutyric acid actions in rat sympathetic neurons. Neuroscience 12:917-927

Bendheim PE, Obstarczyk Reale E, Berg B (1985) $\beta$-Adrenergic treatment of hyperkalemic periodic paralysis. Neurology $35: 746-749$

Brooks JF (1969) Hyperkalemic periodic paralysis. Intracellular myographic studies. Arch Neurol 20:13-18

Camacho LM (1984) Paralisis periodica paramiotonica. Estudio de una familia colombiana. Acta Med Colombiana 9:53-59

Chinet A, Clausen T (1984) Energetics of active sodium-potassium transport following stimulation with insulin, adrenaline or salbutamol in rat soleus muscle. Pflügers Arch 401:160-166

Clausen $\mathrm{T}$ (1986) Regulation of active $\mathrm{Na}^{+}-\mathrm{K}^{+}$transport in skeletal muscle. Physiol Rev 66:542-580

Clausen T, Flatman JA (1977) The effect of catecholamines on Na$\mathrm{K}$ transport and membrane potential in rat soleus muscle. $\mathrm{J}$ Physiol 270:383-414

Clausen T, Flatman JA (1980) Beta ${ }_{2}$-adrenoceptors mediate the stimulating effect of adrenaline on active electronic $\mathrm{Na}^{+}-\mathrm{K}^{+}$ transport in rat soleus muscle. Br J Pharmacol 68:749-755

Clausen T, Wang P, Ørskov H, Kristensen O (1980) Hyperkalemic periodic paralysis. Relationships between changes in plasma water, electrolytes, insulin and catecholamines during attacks. Scand J Clin Lab Invest 40:211-220

Désilets M, Baumgarten CM (1986) Isoproterenol directly stimulates the $\mathrm{Na}^{+}-\mathrm{K}^{+}$pump in isolated cardiac myocytes. Am J Physiol $251: \mathrm{H} 218-\mathrm{H} 225$

Dockry M, Kernan RP, Tagney A (1966) Active transport of sodium and potassium in mammalian skeletal muscle and its modifi- 
cation by nerve and by cholinergic and adrenergic agents. J Physiol 186:187-200

Glitsch HEG, Rasch R (1986) An effect of noradrenaline on resting potential and $\mathrm{Na}$ activity in sheep cardiac Purkinje fibres. Pflügers Arch 406:144-150

Grafe P, Ballanyi K, ten Bruggencate G (1985) Changes of intracellular free ion concentrations, evoked by carbachol or GABA in sympathetic neurons. In: Kessler M, Harrison DK, Höper J (eds) Recent advances in the theory and application of ion selective electrodes in physiology and medicine. Springer, Berlin Heidelberg New York, pp 184-188

Kozachuk WE, Phillis JW (1978) The role of calcium ions in noradrenaline-elicited hyperpolarization of frog skeletal muscle. Gen Pharmacol 9:235-238

Lee CO, Vasalle M (1983) Modulation of intracellular Na-activity and cardiac force by norepinephrine and Ca. Am J Physiol 244: $\mathrm{C} 110-\mathrm{C} 114$

Lehmann-Horn F, Küther G, Ricker K, Grafe P, Ballanyi K, Rüdel $R$ (1987) Adynamia episodica hereditaria with myotonia: a noninactivating sodium current and the effect of extracellular $\mathrm{pH}$. Muscle Nerve (in press)

MacDermott M (1984) The activity coefficient of intracellular sodium in frog skeletal muscles. J Physiol 355:17p

Pfliegler G, Szabó I, Kovács T (1983) The influence of catecholamines on $\mathrm{Na}, \mathrm{K}$ transport in slow- and fast-twitch muscles of the rat. Pflügeres Arch 398:236-240

Rasmussen MK, Clausen T (1982) The stimulating effect of 3'-5'(cyclic) adenosine monophosphate and lipolytic hormones on skeletal muscle of the rat. Biochim Biophys Acta 693:389 -397

Rosa RM, Silva P, Young JB, Landsberg L, Brown RS, Rowe JW, Epstein FH (1980) Adrenergic modulation of extrarenal potassium disposal. N Engl J Med 302:431 - 434

Sheu S-S, Sharma VK, Banerjee SP (1984) Measurement of cytosolic free calcium concentration in isolated rat ventricular myocytes with Quin 2. Circ Res 55:830--834
Steinhagen C, Hirche HJ, Nestle HW, Bovenkamp U, Hosselmann I (1976) The interstitial $\mathrm{pH}$ of the working gastrocnemius muscle of the dog. Pflügers Arch 367:151-156

Thomas RC (1984) Experimental displacement of intracellular $\mathrm{pH}$ and the mechanism of its subsequent recovery. J Physiol 354:3P-22P

Tsien RY, Rink TJ (1981) $\mathrm{Ca}^{2+}$-selective electrodes; a novel PVCgelled neutral carrier mixture compared with other currently available sensors. J Neurosci Meth 4:73-86

Wang P, Clausen T (1976) Treatment of attacks in hyperkalemic familiar periodic paralysis by inhalation of salbutamol. Lancet I: $221-223$

Wasserstrom JA, Schwartz DJ, Fozzard HA (1982) Catecholamine effects on intracellular sodium activity and tension in dog heart. Am J Physiol 243:H670-H675

Weingart R. Hess P (1984) Free calcium in sheep cardiac tissue and frog skeletal muscle measured with $\mathrm{Ca}^{2+}$-selective microelectrodes. Pflügers Arch 402:1-9

Williams ME, Gervino EV, Rosa RM, Landsberg L, Young JB, Silva P, Epstein FH (1985) Catecholamine modulation of rapid potassium shifts during exercise. $N$ Engl J Med 312:823827

Zemkova H, Svoboda P, Teisinger J, Vyskočil F (1985) On the mechanism of catecholamine-induced hyperpolarization of skeletal muscle cells. Naunyn-Schmiedeberg's Arch Pharmacol $329: 18-23$

Received May 6/Received after revision November $12 /$ Accepted November 13, 1987 